\title{
Effect of fly ash reinforcement on the corrosion behaviour of cast Al-Mg alloy A535 in 3.5 wt \% NaCl solution
}

\author{
E. R. Obi ${ }^{1}$, I. N. A. Oguocha ${ }^{1}$ \& R. W. Evitts ${ }^{2}$ \\ ${ }^{I}$ Department of Mechanical Engineering, University of Saskatchewan, \\ Canada \\ ${ }^{2}$ Department of Chemical Engineering, University of Saskatchewan, \\ Canada
}

\begin{abstract}
The effect of fly ash reinforcement on the room temperature corrosion behaviour of cast Al-Mg alloy A535 in 3.5 wt \% pH $7 \mathrm{NaCl}$ solution was investigated using an immersion corrosion test, electrochemical tests and optical microscopy. The materials studied were A535 and its metal matrix composites (MMCs) containing $10 \mathrm{wt} \%$ fly ash, $15 \mathrm{wt} \%$ fly ash, and a hybrid reinforcement ( $5 \mathrm{wt} \%$ fly $\mathrm{ash}+5 \mathrm{wt} \% \mathrm{SiC}$ ). The immersion corrosion test results showed that the corrosion rate of the MMCs increased with increasing fly ash content while the electrochemical test results indicated that their corrosion potential $\left(E_{\text {corr }}\right)$ and critical pitting (breakdown) potential $\left(E_{p}\right)$ decreased with increasing fly ash content. The repassivation potentials of the MMCs were found to be more positive than that of the matrix alloy. The corrosion of the MMCs, which was accompanied by loosening of fly ash particles, was also affected by porosity and the presence of several reaction products.

Keywords: Al-Mg alloy, A535, fly ash, MMCs, corrosion rate, corrosion potential, pitting potential, repassivation potential, intermallic compounds, $\mathrm{Mg}_{2} \mathrm{Si}$.
\end{abstract}

\section{Introduction}

Particle-reinforced aluminum metal matrix composites (MMCs) containing $\mathrm{SiC}$ and $\mathrm{Al}_{2} \mathrm{O}_{3}$ have received great attention in the past few decades because of their improved wear resistance, reduced coefficient of thermal expansion (CTE), high 
elastic modulus, and improved strength compared to unreinforced aluminum alloys $[1,2]$. Although they have found potential applications in weight-critical components in automobile, aerospace, and defence systems [2-5], the application base of these particulate MMCs is limited by their high production cost. Recently, inexpensive aluminum alloy MMCs reinforced with fly ash, a waste by-product of coal combustion, has been engineered [6-11] to serve as a substitute for conventional particulate MMCs in several applications in order to widen the application bases of this class of MMCs. The addition of fly ash into aluminum MMCs is a value-added initiative that lowers the disposal cost of fly ash, increases energy savings by reducing the quantity of aluminum produced, and creates a healthier environment.

Many potential applications of particulate Al MMCs in naval structures such as ship and boat hulls, offshore structures and desalination plants involve exposure to saline environments with high chloride ion concentrations. Also, particulate $\mathrm{Al}$ MMCs used in automobile engine parts usually encounter hostile environments containing chloride, sulphate and nitrate ions as well as exhaust gases like $\mathrm{CO}_{2}, \mathrm{CO}$ and $\mathrm{NO}_{\mathrm{x}}$ [12]. Since corrosion resistance is a key design parameter which must be factored in when considering the application potentials of particulate MMCs in structural applications, it is important to understand the corrosion behaviour of these materials in different corrosive environments.

The corrosion behaviour of Al-based MMCs reinforced with particles such as $\mathrm{Al}_{2} \mathrm{O}_{3}$, garnet, $\mathrm{TiC}, \mathrm{AlN}$ and $\mathrm{SiC}$ particles have been studied by several workers [12-21]. A close look at the results obtained from these studies shows that three types of corrosion can occur in particulate $\mathrm{Al} \mathrm{MMCs}$ at room temperature. These are galvanic corrosion between the reinforcement and the matrix alloy, crevice corrosion around the reinforcement and in surface pores, and pitting corrosion of the matrix alloy as well as the interface between the matrix and the reinforcement.

De Salazar et al [13] investigated the effect of heat treatment and reinforcement volume fraction on the corrosion behaviour of AA6061 and AA7005 reinforced with $\mathrm{Al}_{2} \mathrm{O}_{3}$ particles. They found that the pitting corrosion mechanisms of AA6061 MMCs were affected by post-fabrication heat treatment and that the number of corrosion pits increased with increasing $\mathrm{Al}_{2} \mathrm{O}_{3}$ volume fraction. Gnecco and Beccaria [14] investigated the corrosion behaviour in sea water of a $\mathrm{SiC}_{\mathrm{p}} / \mathrm{Al}-\mathrm{Mg} \mathrm{MMC}$ and found that $\mathrm{SiC}$ particles acted as cathodic sites with respect to the matrix alloy, which experienced selective aluminium dissolution. They also observed that the MMC suffered localized corrosion of the matrix where $\mathrm{Al}-\mathrm{Cu}$ intermetallic compounds were present. Also, Gavgali et al [15] studied the effect of reinforcement content on the corrosion behavior of $\mathrm{SiC}_{\mathrm{p}} / \mathrm{Al}-\mathrm{Si}-\mathrm{Mg}$ MMCs in both aerated and deaerated 3.5wt.\% $\mathrm{NaCl}$ aqueous solutions. The results showed that the corrosion resistance of the MMCs decreased with increasing $\mathrm{SiC}$ particle content. However, Kiourtsidis et al [16] who studied $\mathrm{SiC}_{\mathrm{p}} / \mathrm{AA} 2024$ MMCs reported that the overall performance of the matrix alloy was independent of the volume fraction of SiC particles as they observed no detrimental galvanic attack between the matrix and the particles. 
Similarly, Aylor and Moran [17] observed that $\mathrm{SiC}$ did not alter the corrosion potential of AA6061 in aerated seawater.

Although there is a significant amount of research on the corrosion behavior of $\mathrm{Al}$ alloys and conventional particulate $\mathrm{Al} \mathrm{MMCs,} \mathrm{there} \mathrm{is} \mathrm{a} \mathrm{dearth} \mathrm{of}$ information on the corrosion behaviour of Al alloys reinforced with fly ash particles [9,11]. The present investigation was therefore initiated to contribute to better understanding of the effect of fly ash additions on the corrosion behavior of cast $\mathrm{Al}-\mathrm{Mg}$ alloy $\mathrm{A} 535$ in $3.5 \mathrm{wt} \% \mathrm{NaCl}$ solution. A535 is a non-heat treatable Al-Mg alloy with good combination of strength, machinability, corrosion resistance, weldability and good surface finish. It is used for manufacturing naval vessels, aircraft landing gears, rocket launchers, lightweight armoured vehicles and components of instruments and computing devices.

\section{Experimental materials and procedure}

\subsection{Materials}

The fly ash reinforced A535 MMCs used in this study were fabricated by the stir casting technique. The MMCs contained 10wt $\%$ fly ash (10FA/A535), 15wt $\%$ fly ash (15FA/A535) and a hybrid mixture consisting of $5 \mathrm{wt} \%$ fly ash and $5 \mathrm{wt} \%$ $\mathrm{SiC}$ (5FA5SiC/A535). The composition of the A535 alloy used was $6.17 \mathrm{wt} \%$ $\mathrm{Mg}, 0.01 \mathrm{wt} \% \mathrm{Cu}, 0.01 \mathrm{wt} \% \mathrm{Si}, 0.02 \mathrm{wt} \% \mathrm{Fe}$, and $0.04 \mathrm{wt} \% \mathrm{Ti}$, bal. Al while the composition of the raw fly ash used is shown in Table 1.

Table 1: $\quad$ Weight percent of various oxides in fly ash.

\begin{tabular}{|c|c|c|c|c|c|c|c|c|c|}
\hline Compound & $\mathrm{SiO}_{2}$ & $\mathrm{Al}_{2} \mathrm{O}_{3}$ & $\mathrm{Fe}_{2} \mathrm{O}_{3}$ & $\mathrm{MgO}$ & $\mathrm{CaO}$ & $\mathrm{TiO}_{2}$ & $\mathrm{~K}_{2} \mathrm{O}$ & $\mathrm{Na}_{2} \mathrm{O}$ & $\mathrm{SO}_{3}$ \\
\hline Weight \% & 44.8 & 22.2 & 24.0 & 0.9 & 1.8 & 0.8 & 2.4 & 0.9 & 1.4 \\
\hline
\end{tabular}

Balance $=$ oxides of other trace elements.

\subsection{Corrosion testing}

The corrosion behavior of the test materials was evaluated using static immersion test, potentiodynamic and cyclic polarization tests, visual inspection and optical microscopy. The immersion test was conducted at room temperature using conventional weight loss method (ASTM G31) to an accuracy of $0.0001 \mathrm{~g}$. Rectangular specimens measuring $10 \mathrm{~mm} \times 10 \mathrm{~mm}$ x $5 \mathrm{~mm}$ were cut from the A535 and its MMCs, metallurgically polished with emery cloth to high smoothness, cleaned ultrasonically in acetone and methanol, and dried. They were subsequently weighed and immersed in a solution of $3.5 \mathrm{wt} \% \mathrm{NaCl}(\mathrm{pH}=$ 7) exposed to the ambient air. The specimens were suspended in the electrolyte using a plastic string and a plastic crocodile clip to avoid crevice and galvanic corrosion. The specimens were removed from the solution at regular intervals and cleaned in accordance with ASTM G1-90 standard, dried and re-weighed. The exposure times used in this study were 1, 3, 5, 7, 10, and 14 days. The surface of each specimen was examined visually and by optical microscopy before and after each exposure test. 
Electrochemical polarization measurements were conducted on all specimens of the matrix alloy and composites using a Gamry ECM 8 electrochemical multiplexer with PCI4 potentiostat controlled by a computer. A saturated calomel electrode (SCE) and a graphite electrode were used as reference and auxiliary electrodes, respectively. As in the immersion test, all specimens were metallurgically polished to high smoothness using emery cloth, rinsed in acetone, dried, and immersed in a $3.5 \mathrm{wt} \% \mathrm{pH} 7 \mathrm{NaCl}$ electrolyte at room temperature exposed to the atmospheric air. Before starting the measurements, all specimens were allowed to equilibrate for approximately 30 minutes to their corrosion potential $\left(E_{\text {corr }}\right)$. A scan rate of $1 \mathrm{mV} / \mathrm{s}$ was used to determine the corrosion potential $\left(E_{c o r r}\right)$, pitting potential $\left(E_{p}\right)$ and repassivation potential $\left(E_{r p}\right)$.

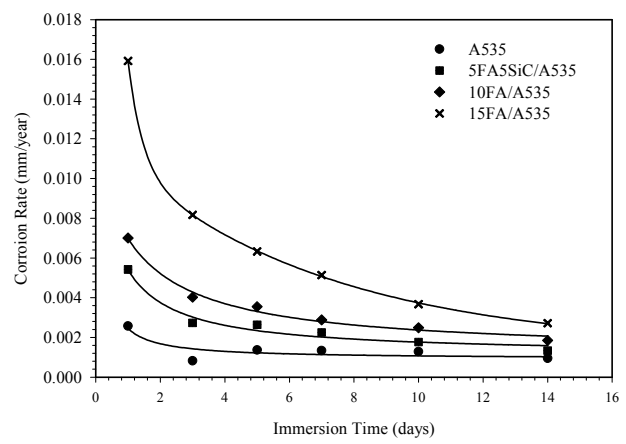

Figure 1: Variation of corrosion rate of A535 and its fly ash reinforced MMCs with time in $3.5 \mathrm{wt} \% \mathrm{NaCl}$ solution $(\mathrm{pH}=7)$.

\section{Results and discussion}

Fig. 1 shows the variation of corrosion rate with exposure time for specimens immersed in $3.5 \mathrm{wt} \% \mathrm{NaCL}(\mathrm{pH}=7)$ solution at room temperature. It can be seen that the matrix alloy (A535) and its composites showed similar corrosion behaviour. The corrosion rate of all the tested materials decreased rapidly during the first three days of exposure to the electrolyte but, with further exposure time, the decrease was very gradual. Passivation of the matrix alloy is believed to be responsible for the phenomenon of monotonically decreasing corrosion rate with increasing exposure time observed in these materials [12]. It is also seen that 15FA/A535 composite showed the highest rate of corrosion, followed in decreasing order by $10 \mathrm{FA} / \mathrm{A} 535,5 \mathrm{FA} 5 \mathrm{SiC} / \mathrm{A} 535$, and A535. It was also observed that the corrosion of the composites was accompanied by loosening of fly ash particles, with the amount of loosened fly ash being greatest in 15FA/A535 composite, followed by 10FA/A535 composite. It was believed that the corrosion of the fly ash-matrix interface caused the loosening of fly ash particles which were finally dislodged from the specimens during postimmersion cleaning process. Ramachandra and Radhakrishna [11] have reported that fly ash particles acted as pit initiation sites in Fly ash/Al-Si alloy composites 
and that there was a buildup of corroded fly ash particle debris in corrosion pits. The loss of such particles during contributed to the high weight loss recorded for the MMCs in the present study.

The effect of fly ash addition on the corrosion potential of A535 alloy is shown in Fig. 2 where curves of potential versus current density obtained via potentiodynamic polarization measurements are plotted for the tested materials. It can be seen that all the curves are similar indicating that polarization behaviour of unreinforced A535 alloy and its composites is similar. The corrosion potential $\left(E_{c o r r}\right)$ of the unreinforced alloy is more positive than that of the composites which tends to increase with increasing fly ash content. The corrosion potential of A535 alloy is $-415 \mathrm{mV}$ (SCE) while those of 10FA/A535 and 15FA/A535 composites are $-443 \mathrm{mV}$ (SCE) and $-507 \mathrm{mV}$ (SCE), respectively. Hence, the unreinforced A535 alloy is more noble than its MMCs. Similar results have been reported by Bienias et al [9] for fly ash/AL-Si alloy composites.

Fig. 3 shows the cyclic potentiodynamic polarization curves obtained for A535 alloy and its fly ash-reinforced MMCs immersed in $3.5 \mathrm{wt} \% \mathrm{NaCl}(\mathrm{pH}=7)$ while Figs 4 and 5 show respectively the variation of critical pitting potential $\left(E_{p}\right)$ and repassivation potential $\left(E_{r p}\right)$ with increasing fly ash content. Fig. 4 shows that the $E_{p}$ of the tested materials became more negative with the addition of fly ash. It decreased from about $166 \mathrm{mV}$ in A535 to $-237.8 \mathrm{mV}$ in 15FA/A535 composites, indicating that A535 alloy has better pitting corrosion resistance in $3.5 \mathrm{wt} \% \mathrm{NaCl}$ solution than its composites. On the other hand, Fig. 5 shows that $E_{r p}$ increases (in the active direction) with increasing fly ash content. It increased from $-822.5 \mathrm{mV}$ (SCE) in A535 alloy to $-799.3 \mathrm{mV}$ (SCE) in 15FA/A535 composite. Since $E_{r p}$ measures the ability of a material to repassivate, the present results show that pit propagation in the composites is retarded more than in the matrix alloy. A measure of the tendency for pits to nucleate in a material is given by the difference between $E_{p}$ and $E_{c o r r}$. Thus, the ability of a material to resist pit initiation during localized corrosion increases as the value of $E_{p}-E_{c o r r}$ becomes larger [20]. Fig. 6 shows a plot of $E_{p}-E_{\text {corr }}$ for the materials studied. It can be seen that A535 alloy has superior pitting corrosion resistance to the composites.

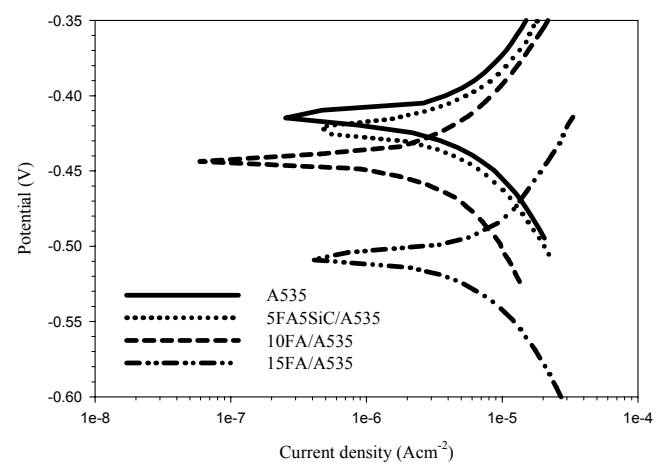

Figure 2: $\quad$ Potentiodynamic polarization curves for A535 alloy and its fly ash reinforced $\mathrm{MMCs}$ in $3.5 \mathrm{wt} \% \mathrm{NaCl}$ solution $(\mathrm{pH}=7)$. 


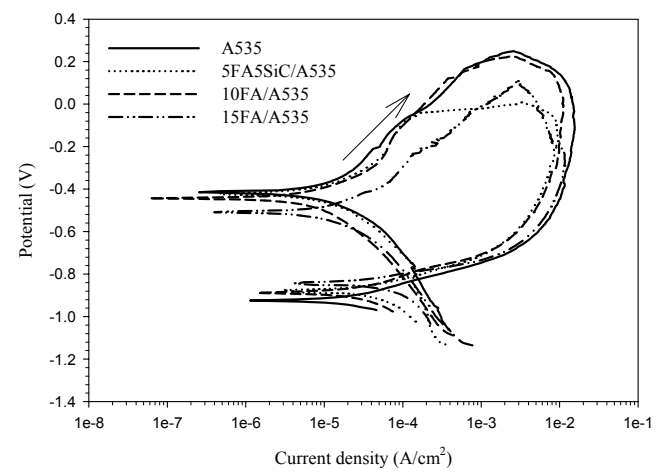

Figure 3: Cyclic potentiodynamic polarization curves for A535 and its MMCs in $3.5 \mathrm{wt} \% \mathrm{NaCl}$ solution $(\mathrm{pH}=7)$.

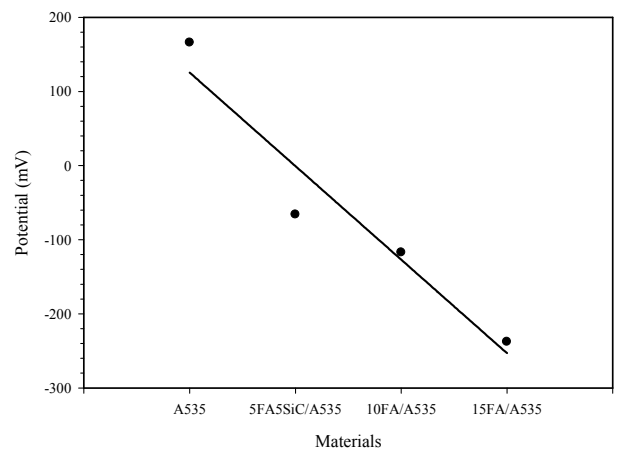

Figure 4: Effect of fly ash content on the pitting potential of A535 and its MMCs.

The corrosion behaviour of particulate Al MMCs is influenced by several factors such as porosity, high dislocation densities at the matrix-reinforcement interfaces, the presence of intermetallic compounds (IMCs) and reaction products, and the electrical conductivity of the reinforcing phases [19]. Gikunoo and Oguocha [24] have reported that the amount of dimagnesium silicide, $\mathrm{Mg}_{2} \mathrm{Si}$, and spinel, $\mathrm{Al}_{2} \mathrm{MgO}_{4}$, in fly ash/A535 composites increased with increasing fly ash content. $\mathrm{Mg}_{2} \mathrm{Si}$ is produced in the matrix alloy through a solid-state reaction between $\mathrm{Si}$ and $\mathrm{Mg}$

$$
2 \mathrm{Mg}+\mathrm{Si} \leftrightarrow \mathrm{Mg}_{2} \mathrm{Si}
$$

In the MMCs, the $\mathrm{SiO}_{2}$ phase present in fly ash particles or covering the surface of $\mathrm{SiC}$ particles in 5FA5SiC/A535 composite is reduced by molten magnesium through a two-step reaction leading to the formation of the $\mathrm{Mg}_{2} \mathrm{Si}$ phase:

$$
\begin{gathered}
2 \mathrm{Mg}+\mathrm{SiO}_{2} \leftrightarrow 2 \mathrm{MgO}+\mathrm{Si} \\
2 \mathrm{Mg}+\mathrm{Si} \leftrightarrow \mathrm{Mg}_{2} \mathrm{Si}
\end{gathered}
$$


The spinel phase is formed in the MMCs via a reaction between elemental magnesium of the matrix alloy and fly ash constituents, particularly the alumina $\left(\mathrm{Al}_{2} \mathrm{O}_{3}\right)$ and quartz phases, following either of the chemical reactions:

$$
\begin{gathered}
3 \mathrm{Mg}+4 \mathrm{Al}_{2} \mathrm{O}_{3} \leftrightarrow 2 \mathrm{Al}+3 \mathrm{MgAl}_{2} \mathrm{O} 4 \\
2 \mathrm{SiO}_{2}+2 \mathrm{Al}+\mathrm{Mg} \leftrightarrow \mathrm{MgAl}_{2} \mathrm{O}_{4}+2 \mathrm{Si}
\end{gathered}
$$

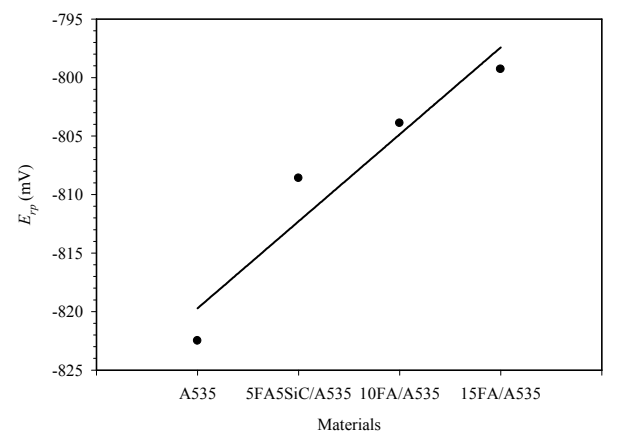

Figure 5: Effect of fly ash content on the repassivation potential of A535 and its MMCs.

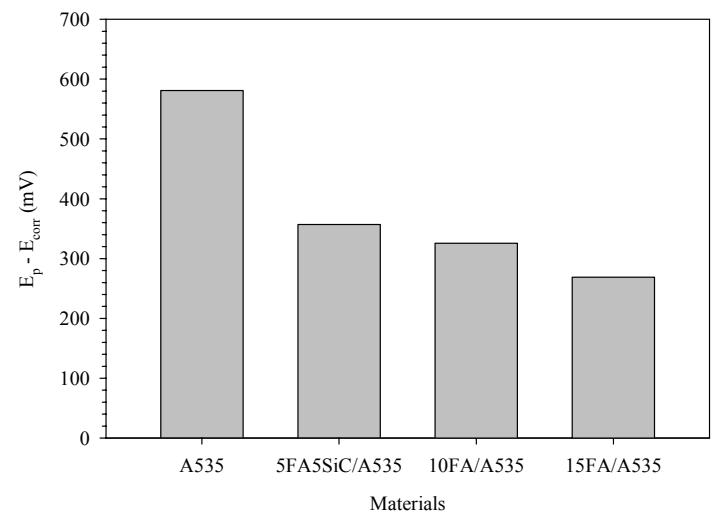

Figure 6: Plot of $E_{p}-E_{\text {corr }}$ for A535 alloy and its MMCs in $3.5 \mathrm{wt} \% \mathrm{NaCl}$ solution $(\mathrm{pH}=7)$.

The presence of the intermetallic phases and porosities in the MMCs serve as preferential sites for localized corrosion. In the present study, optical microscopy observation of the corroded surfaces of specimens immersed in $\mathrm{NaCl}$ solution for several days showed that pits occurred where the $\mathrm{Mg}_{2} \mathrm{Si}$ phase existed prior to immersion. This was well pronounced in the matrix alloy thus indicating that $\mathrm{Mg}_{2} \mathrm{Si}$ has a less noble potential than the alloy in $3.5 \mathrm{wt} \% \mathrm{NaCl}$ solution at room temperature. It was reported by Birbilis [22] that $\mathrm{Mg}_{2} \mathrm{Si}$ does not show any breakdown potential and is capable of corroding freely above its $E_{\text {corr }}$, which was 
measured to be $-1536 \mathrm{mV}$ (SCE) in $0.6 \mathrm{M} \mathrm{NaCl}$ [22] and -1530 to $-680 \mathrm{mV}$ (SCE) in $3 \mathrm{wt}^{2} \% \mathrm{NaCl}$ [23] as compared to $-849 \mathrm{mV} \mathrm{SCE}$ for pure aluminum in $0.6 \mathrm{M} \mathrm{NaCl}$ [22] and -760 to $-810 \mathrm{mV}$ (SCE) for Al-Mg binary alloy in $53 \mathrm{~g} / 1$ $\mathrm{NaCl}+3 \mathrm{~g} / \mathrm{l} \quad \mathrm{H}_{2} \mathrm{O}_{2}$ solution [23]. Since aluminum is noble to $\mathrm{Mg}_{2} \mathrm{Si}$, the microgalvanic couple formed between them in A535 alloy and its MMCs would selectively corrode $\mathrm{Mg}_{2} \mathrm{Si}$ away. Therefore, the deep pits observed in the A535 alloy are attributed to the dissolution of the $\mathrm{Mg}_{2} \mathrm{Si}$

\section{Conclusions}

1 The corrosion rate of fly ash/A535 MMCs immersed in $3.5 \mathrm{wt} \% \mathrm{NaCl}$ solution at room temperature was higher than that of the matrix alloy and increased with increasing fly ash content.

2 Fly ash/A535 MMCs showed increased susceptibility to pitting corrosion compared to the unreinforced $\mathrm{A} 535$ alloy in $\mathrm{NaCl}$ solution. The pitting potential $\left(E_{p}\right)$ of the composites decreased with increasing fly ash content.

3 The sites for pit initiation in A535 alloy were the intermetallic compounds, especially the $\mathrm{Mg}_{2} \mathrm{Si}$ phase which dissolved away with increasing immersion time.

4 The predominant pit initiation sites in the MMCs were the interfaces between the matrix alloy and fly ash and intermetallic compounds such as $\mathrm{Mg}_{2} \mathrm{Si}$ and $\mathrm{Al}_{2} \mathrm{MgO}_{4}$.

\section{Acknowledgement}

This work was supported by the Natural Sciences and Engineering Research Council of Canada via a discovery grant to I. N. A. Oguocha.

\section{References}

[1] Chawla, N. \& Shen Y., Mechanical Behavior of Particle Reinforced Metal Matrix Composites. Advanced Engineering Materials, 3(6), pp. 357-370, 2001.

[2] Lloyd, D.J., Particle-Reinforced Aluminum and Magnesium Matrix Composites. International Materials Reviews, 39(1), pp. 1-23, 1994.

[3] Fujine, M, Kaneko, T, \& Okijima, J, Adv. Mater. Process, 143(6), pp. 2021, 1993.

[4] Akbulut, H, Durman, M \& Yilmaz, F, Scripta Materialia, 36, pp. 835-840, 1997.

[5] Goni, J, Mitxelena, I, \& Coleto, J, Mater. Sci. Technol., 16, pp.743-746, 2000

[6] Rohatgi, P.K, Kim, J.K, Guo, R.Q, Robertson, D.P \& GajdardziskaJosifovska, M, Age-hardening characteristics of aluminum alloy-hollow fly ash composites, Metall. Mater. Trans., 33A, pp. 1541-1547, 2002. 
[7] Golden, D, Ashalloys: aluminum-fly ash composites. EPRI Journal, 19(1), pp. 46(4), 1994.

[8] Guo, R.Q \& P K Rohatgi, P.K, Chemical reactions between aluminum and fly ash during synthesis and reheating, Metall. Mater. Trans., 29B, pp. 519-525, 1998.

[9] Bienias, J, Walczak, M,. Surowska, B \& Sobczak, J., Microstructure and Corrosion Behaviour of Aluminum Fly Ash Composites. Journal of Optoelectronics and Advanced Materials, 5(2), pp. 493-502, 2003.

[10] Gikunoo, E., Omotoso, O. \& Oguocha, I.N.A., Effects of Fly Ash Particles on the Mechanical Properties of Aluminum Casting Alloy 535. Material Science and Technology, 21(2), pp. 143-152, 2005.

[11] Ramachandra, M \& Radhakrishna, K., Microstructure, Mechanical Properties, Wear and Corrosion Behaviour of Al-Si/flyash Composite, Materials Science and Technology, 21(11), pp. 1337-43, 2005.

[12] Seah, K.H. W, Krishna, M., Vijayalakshmi, V.T. \& Uchil, J., Corrosion Behaviour of Garnet Particulate Reinforced LM13 Al Alloy MMCs, Corrosion Science, 44, pp. 917-925, 2002.

[13] De Salazar, J.M.G., Urena, U., Manzanedo, S. \& Barrena, M.I., Corrosion behaviour of AA6061 and AA7005 reinforced with $\mathrm{Al}_{2} \mathrm{O}_{3}$ Particulates in Aerated 3.5\% Chloride Solutions: Potentiodynamic Measurements and Microstructure Evaluation, Corrosion Science, 41, pp. 529-545, 1999.

[14] Gnecco, F.F, Corrosion Behaviour of Al-Si/SiC Composite in Sea Water. British Corrosion Journal, 34(1), pp. 57-62, 1999.

[15] Gavgali, M., Dikici, B. \& Tekmen, C., The effect of $\mathrm{SiC}_{\mathrm{p}}$ Reinforcement on the Corrosion Behaviour of Al Based Metal Matrix Composites, Corrosion Reviews, 24(1-2), pp. 27-37, 2006.

[16] Kiourtsidis, G \& Skolianos, M., Corrosion Behavior of Squeeze-cast Silicon carbide-2024 composites in aerated 3.5 wt.\% sodium chloride. Materials Science and Engineering, A248, pp. 165-172, 1998.

[17] Aylor, D.M \& Moran, P.J, Effect of Reinforcement on the Pitting Behavior of Aluminum-Base Metal Matrix Composites. Journal of The Electrochemical Society, 321(6), pp. 1277-1281, 1985.

[18] Candan, S. \& Bilgic, E., Corrosion Behavior of Al-60 Vol. $\% \mathrm{SiC}_{\mathrm{p}}$ Composites in NaCl Solution. Materials Letters, 58, pp. 2787-2790, 2004.

[19] Albiter, A., Contreras, A., Salazar, M. \& Gonzalez-Rodriguez, J.G, Corrosion Behaviour of Aluminium Metal Matrix Composites Reinforced with TiC Processed by Pressureless Melt Infiltration, Journal of Applied Electrochemistry, 36 (3), pp. 303-308, 2006.

[20] Pardo, A., Merino, M.C., Merino, S., Viejo, F., Carboneras, M. \& Arrabal, R., Influence of Reinforcement Proportion and Matrix Composition on Pitting Corrosion Behaviour of Cast Aluminium Matrix Composites (A3xxx.x/SiCp). Corrosion Science, Vol. 47, Issue 7, 2005, pp. 17501764.

[21] . A. Pardo, M. C. Merino, F. Viejo, S. Feliu, Jr., M. Carboneras and R. Arrabal, Corrosion Behavior of Cast Aluminium Matrix Composites 
(A3xxx.x/SiCp) in Chloride Media. Journal of Electrochemical Society, 152(6), pp. B198-B204, 2005.

[22] Birbilis, N.N., Electrochemical Characteristics of Intermetallic Phases in Aluminum Alloys: An Experimental Survey and Discussion. Journal of The Electrochemical Society, 152(4), pp. B140-B151, 2005.

[23] Buchheit, R. G, Compilation of Corrosion Potentials Reported For Intermetallic Phases in Aluminium Alloys. Journal of The Electrochemical Society, 142(11), pp. 3994-3996, 1995.

[24] Gikunoo, E. \& Oguocha, I.N.A. Proc. Of the 6th Joint Canada-Japan Workshop on Composites, ed. J. Lo, T. Nishino, S.V. Hoa, H. Hamada, A. Nakai, C. Poon, DEStech Publications, Inc., Toronto, Canada, pp. 387396, 2006. 